\title{
Polanyi's Double Movement: A Critical Reappraisal
}

\author{
EPPo MaERTEns \\ Carleton University
}

Social scientists have been paying increasing attention to the works of Karl Polanyi. Of particular interest has been his claim that the (re)structuring of the economy based on the ideals of the self-regulating market inevitably leads society to reassert itself against the commodification of land, labour and money. Referred to as the "double movement," this idea has been used by many scholars to challenge the underlying logic of free-market principles and to explain popular resistance to reforms based on it. There are two aspects of Polanyi's double movement. The first refers to the push for free market reforms by various groups in society. The second refers to the counter-movements that he argues necessarily and spontaneously mobilize against it. Many who draw on Polanyi focus on the second aspect and how it might apply to contemporary debates. Less attention has been paid to the contemporary applicability of the first aspect. In this paper I argue that this is an area that deserves further attention, both from those who wish to apply his ideas as well as from those who wish to challenge them.

\section{Introduction}

Over the past 25 years social scientists, especially those with an interest in political economy, have been paying increasing attention to the works of Karl Polanyi. Of particular interest has been his

Eppo Maertens is a $\mathrm{PhD}$ student in sociology at Carleton University in the School of Public Policy and Administration. Inquiries should be sent to e_maertens@ hotmail.com. 
claim that the (re)structuring of the economy, and society more generally, based on the ideals of the self-regulating or free market inevitably leads society to reassert itself against the commodification of land, labour and money. Referred to as the "double movement," this idea has been used by many scholars to challenge the underlying logic of free market principles and to explain popular resistance to the way in which those principles have influenced the development of capitalism. There are two aspects of Polanyi's double movement. The first aspect refers to the push for free market reforms by various groups in society. The second aspect refers to the counter movements that he argues necessarily and spontaneously mobilize against it. Many of those who draw on Polanyi's work have tended to focus their attention on the second aspect of the double movement and how it might be applied to contemporary debates. ${ }^{1}$ Attention has also been paid to his historical account of the rise of $19^{\text {th }}$ century capitalism. ${ }^{2}$ Less attention has been paid to examining how the first aspect of the double movement might be applied in current contexts. In this paper I argue that this is an area that deserves further attention, both from those who wish to apply his ideas as well as from those who wish to challenge them.

This paper starts by examining this first aspect of the double movement and asks why the idea of the self-regulating or free market — which Polanyi argues was applied with such devastating

${ }^{1}$ See for example: Giovanni Arrighi, "Hegemony Unravelling” in New Left Review, March/April 2005, p. 42 and Jürgen Habermas, "The Postnational Constellation and the Future of Democracy" in The Postnational Constellation: Political Essays (Max Pensky, ed. and trans.), Cambridge: MIT Press, 2001, particularly p. 85.

${ }^{2}$ It should be noted that Polanyi rarely uses the word capitalism in The Great Transformation, writing instead of the emergence of the "self-regulating market" (1957, 71). Accordingly, contemporary writers have stressed his concern with explaining the emergence of $19^{\text {th }}$ English capitalism while at the same time stressing that his account transcends the analysis of capitalism per se. For example, Baum argues The Great Transformation "offers a critical examination of the industrial capitalism set up in England in the early part of the nineteenth century" but adds "his critique of the emerging economy ... transcends the traditional debate between capitalism and socialism" (3-4). Block and Somers describe The Great Transformation more generally as telling "of the conflict between the imperatives of a capitalist world economy and the pursuit of social welfare within nation-states" (48). In another paper, which will be examined more closely below, Block argues that Polanyi's reluctance to speak of capitalism marked and important theoretical shift in his thinking (280). 
consequences in the $19^{\text {th }}$ century and which was forcefully challenged by powerful counter movements from a broad cross section of society - has proved so persistent and pervasive. Why, in other words, does this idea continue to enjoy a certain popular appeal and to exert a significant influence on public policy? I will argue that Polanyi offers only a specific macro-level historical explanation of $19^{\text {th }}$ century capitalism which resonates with Marxist accounts, but which is not itself based on any discernable theory. It cannot therefore be readily generalized or linked with the micro-level conception of human agency which grounds Polanyi's own explanation of the second aspect of the double movement. This renders his account of the double movement incomplete. To put it another way: Baum argues that Polanyi "holds that the conflict between the self-regulating market and civil society is a permanent characteristic of capitalist countries. He also maintains that the self-regulating market and democracy are in the long run irreconcilable" (1996:12; emphasis added). This may be so, but Polanyi does not explain why capitalism persists in the face of that long run irreconcilability. I will attempt to fill this lacuna by developing a more general theory of the first aspect of the double movement. Based on an interpretation of Hegel's Phenomenology of Spirit and a paper by Nedelsky, I will argue that this theory is compatible with the micro-level conception of human agency of Polanyi's second aspect. I will then briefly examine how this amended account might fit with one contemporary application of Polanyi's double movement which seeks to understand recent moves towards global financial deregulation. Finally, I will argue that, while this theory improves the completeness and consistency of Polanyi's insights and provides a genuine alternative to the Marxist tradition, it may not necessarily pose a particular challenge to the latter perspective.

\section{The Separateness/Embeddedness Distinction: A Conceptual Framework}

The first aspect of Polanyi's double movement, the late- $18^{\text {th }}$ and early- $19^{\text {th }}$ century push for a self-regulating market, is associated with the general idea of a separation of the economy from a 
broader system of societal norms and practices. Polanyi sometimes refers to this notion as "separateness" and contrasts it with "embeddedness" (1977:48; "separateness" has also been referred to as "disembeddeness" and for stylistic purposes I will use the terms interchangeably). In this section I will give a brief account of the way in which Polanyi develops this distinction in historical and anthropological terms. This will be followed in the next section by an examination of some ways in which contemporary scholars have interpreted this distinction, as well as a consideration of Polanyi's use of it in the specific context of political economy.

Historically speaking, Polanyi associates the embedded market most closely with pre-capitalist society. Thus, during the earlier periods of human history, the "economic system was absorbed in the social system" and the "self-regulating market was unknown" (1957:71). On the other hand, $19^{\text {th }}$ century capitalism was informed by "assumptions" of separateness or self-regulation:

Nothing must be allowed to inhibit the formation of markets, nor must incomes be permitted to be formed otherwise than through sales. Neither must there be any interference with the adjustment of prices to changed market conditions - whether the prices are those of goods, labor, land, or money. Hence there must not only be markets for all elements of industry, but no measure or policy must be countenanced that would influence the action of these markets. Neither price, nor supply, nor demand must be fixed or regulated; only such policies and measures are in order which help to ensure the self-regulation of the market by creating conditions which make the market the only organizing power in the economic sphere (1957:72).

He expands on this idea in his essay The Economy Embedded in Society: "It was characteristic of the economic system of the nineteenth century that it was institutionally distinct from the rest of society." Production and distribution is organized through "a self-regulating system of markets" and other institutions which are "activated through economic motives and governed by economic laws." It is based on the idea that humans are "motivated in the last resort by two simple incentives, fear of hunger and hope of gain" (1977:47). 
As Polanyi suggests, the idea of a separation between the economy and society more broadly is one with which modern readers will be conversant. However, the concept of embeddedness is less familiar. In the first place, it entails adopting a broader perspective on the term "economic," understanding it to comprise the "behavior traits relating to the production and distribution of material goods" (Polanyi 1977:52). In contrast, the idea of separateness implies a more limited view, understanding those behaviour traits in terms of "the individual motives of hunger and gain" (Polanyi 1977: 52). For Polanyi, the focus on hunger and gain tends to obscure the broader social context in which economic activity takes place. Hechter makes this point by contrasting Polanyi's embedded understanding of individual action as "determined by social institutions" with the utilitarian view "that man acts rationally to pursue selfish ends that are determined on the basis of certain intrinsic (biologically or psychologically derived) desires" (1981:402).

As the basis of a general economic theory, the separation perspective is somewhat misleading for Polanyi since "never before our own time were markets more than accessories of economic life"(1957:71). The reference to "our time" is somewhat open-ended, but can be taken to refer to the period during which capitalism was intellectually and institutionally born. According to Polanyi, economic activity before this time, while certainly fulfilling basic human needs, did not only serve to fulfil those needs and was not primarily driven by a fear of hunger. Furthermore, it was not motivated by a hope of gain. Rather, "the production and distribution of material goods was embedded in social relations of a noneconomic kind" (1977:51). While certainly fulfilling basic human needs, the way in which these activities were carried out "was simply a byproduct of the working of other, noneconomic institutions" (52).

By way of illustration, Polanyi discusses Bronislaw Malinowski's accounts of the Trobriand Islanders. Here material subsistence was achieved in part through the institution of reciprocity, which can involve an exchange between two parties or a larger sequence of exchanges among different parties fulfilling complementary social roles. For example, Trobriand males were expected to grow garden produce for the households of their married 
sisters. Those males were similarly provided with garden produce by the brothers of their wives. This provided a source of food, but the economic function of the practice was secondary to the function of strengthening social cohesion. On the individual level, according to Polanyi, reciprocity is not motivated by a desire for gain, "the controlling motives being noneconomic, e.g. pride in public recognition of civic virtues as a brother or gardener" (1977:50) Reciprocity in the form of gift exchanges also governed the Trobriand's trade with distant groups. Here also economic gain was not the governing principle: "The whole institution acted to minimize rivalry and conflict and maximize the joy of giving and receiving gifts" (Polanyi 1977:51). From these and other examples, Polanyi concludes:

The result of all these characteristics of primitive societies is the impossibility of organizing the economy, even in thought, as an entity distinct from the social relations in which its elements are embedded. There is, however, no need to organize it either, since the social relationships integrated in the noneconomic institutions of society automatically take care of the economic system. In tribal society the economic process is embedded in the kinship relations that formalize the situations out of which organized economic activities spring (1977:55).

Returning to Polanyi's historical account in The Great Transformation, he describes the move from an embedded economy to an economy based on the idea of a self-regulated market as a gradual process which begins with the commodification of land and money and culminates in the commodification of labour. ${ }^{3}$ Land, labour and money are essential components of industrial production. Accordingly, in the logic of self-regulation, which insists on "markets for all elements of industry" (Polanyi 1957:72) they must be organized accordingly: "in fact, these markets form an absolutely vital part of the economic system" (75). But land, labour and money can never be genuinely commodified and the attempt to do so has devastating consequences. Genuine commodities are goods that are produced for sale. In contrast:

\footnotetext{
3 "The market for labor was, in effect, the last of the markets to be organized under the new industrial system" (Polanyi 1957: 81).
} 
Labor is only another name for a human activity which goes with life itself, which in its turn is not produced for sale but for entirely different reasons, nor can that activity be detached from the rest of life, be stored or mobilized; land is only another name for nature, which is not produced by man; actual money, finally, is merely a token of purchasing power which, as a rule, is not produced at all, but comes into being through the mechanism of banking or state finance (Polanyi 1957:75-76).

At first glance, this appears to be a rather abstract formulation and an arbitrary conceptual move effected by definitional fiat. But the idea, for Polanyi, is empirically based. Faced with the economic uncertainty that unregulated markets imply, humans would face the constant prospect, and at times the stark reality, of unemployment, starvation and a myriad of other ills. This would threaten them physically, but perhaps more importantly, it would threaten them psychologically and socially: "Robbed of the protective covering of cultural institutions, human beings would perish from the effects of social exposure; they would die as the victims of acute social dislocation through vice, perversion, crime, and starvation" (Polanyi 1957:81). Polanyi makes related claims about the attempt to commodify land and money (81). Baum sums up Polanyi's position as follows: "The damage caused by the self-regulating market tore apart the cultural bonds - the values and the inherited institutions - by which people constituted their identity. The new economic system created a devastating anomie which seriously damaged the humanity of workers and affected the whole of society and its relation to the natural environment" (Baum, 1996:9).

This point marks a kind of culmination of the first aspect of the double movement. But Polanyi argues that this was not a state of affairs that could persist. The result of this widespread anomie is the spontaneous emergence of counter movements, the second aspect of the double movement. In $19^{\text {th }}$ century England, these embraced a wide variety of issues, including restrictions on child labour, workplace safety standards, public libraries, enforced vaccinations and price controls. But perhaps more significantly, these movements emerged from a broad cross section of society. They were spontaneous, loosely organized and not tied to any particular ideology. 
In fact, many "collectivist" reformers were individuals who were, more generally, advocates of economic liberalism. The move toward separateness was thus met by spontaneous counter-movements that sought to protect society by ensuring the economy remained embedded in society. To Polanyi, this comes as no surprise: "For if market economy was a threat to the human and natural components of the social fabric, as we insisted, what else would one expect than an urge on the part of a great variety of people to press for some sort of protection" (1957:156).

As I noted in the introduction, Polanyi's conception of the second-aspect of the double movement is grounded in a microlevel conception of human agency which is generalizable beyond the specific context about which he was writing. In the following section I will consider this conception and relate it to the embeddedness/separateness distinction.

\section{The Separateness/Embeddedness Distinction: A Practical Impossibility}

Hechter argues that one of the most important themes in The Great Transformation is the contrast between Polanyi's embedded perspective and the utilitarian view of action. As noted above, he highlights Polanyi's engagement in the debate between the utilitarian claim "that man acts rationally to pursue selfish ends that are determined on the basis of certain intrinsic (biologically or psychologically derived) desires," on the one hand, and early sociological theories which insisted that "individual action was determined by social institutions," on the other (1981:402). Hechter suggests that, in defending the latter perspective, Polanyi's main theoretical contribution was in applying this embedded perspective to capitalist societies.

Lie similarly stresses Polanyi's emphasis on the "embeddedness of economic activities and institutions and the historical relativity of economic concepts" (1991:219). But Lie disagrees with Hechter's suggestion that Polanyi applied this embedded perspective to capitalist societies. He argues that the latter's equation of market society with the commodification of land, labour and money is at odds 
with the idea of embeddedness, since it basically concedes that the utilitarian (or in Lie's terminology, neoclassical) lens is the correct one through which to view society once the great transformation from an economy embedded in society to a society embedded in an economy has been effected. In other words, he suggests that Polanyi takes a "disembedded" view of capitalist society. He argues that this creates difficulties. In particular, it obscures the fact that even in capitalistic market societies, action continues to be informed by social norms and practices. Polanyi's failure to recognize this, Lie argues, means that "Social actors, their interactions, social practices, institutions, and other features remain hidden beneath the veil of the neoclassical concept of the market" (1991:226).

It is also worth noting that, if Lie is correct, this would put the second aspect of the double movement into jeopardy. Lie devotes little attention to the second aspect, being primarily concerned with Polanyi's account of the rise of market society. However, he cites Polanyi's assertion that in market society, "Instead of [the] economy being embedded in social relations, social relations are embedded in the economic system" (Polanyi 1957:57), and interprets this as suggesting that when the economy is organized according to the principles of the self-regulated market, social relations will be too; people will see themselves, and act as rational beings pursuing their own ends. However, the counter-movements that make up the second aspect of the double movement are viewed by Polanyi as "social" movements which are motivated by a desire to protect society from the dangers of the self-regulating market. Such movements would not be compatible with the neoclassical view of action which Lie insists Polanyi takes in relation to capitalist societies.

Lie is sympathetic to Polanyi's critique of capitalist society, but given his interpretation of Polanyi's work, he finds it incomplete. As an alternative, he suggests Polanyi's embedded perspective be extended to capitalist societies, advocating an "embedded analysis of "markets" which would allow "accumulated sociological insights back into the discourse on commodity exchange" (1991:227; this would also eliminate the problem with the second aspect which I outlined in the above paragraph). But to some interpreters, Lie's assertion that Polanyi is advocating anything other than an embed- 
ded analysis of markets may seem curious. In fact, Polanyi seems to stress that land, labour and money are empirically speaking not commodities but are only ever regarded as commodities: "labor, land, and money are obviously not commodities . . . The commodity description of labor, land and money is entirely fictitious" (Polanyi 1957:75). This leads Hechter to argue that land, labour and money are never actually commodified and that capitalist society is in fact viewed by Polanyi from an embedded perspective. He argues that Polanyi's insistence that "man's economy, as a rule, is submerged in his social relationships" and that humans are driven by social interests and noneconomic motives in a "small hunting or fishing community" just as in "a vast despotic society" (Polanyi 1957:46) applies equally to "Homo Oeconomicus" and "primitive man" (Hechter 1981:406). While Hechter sees some separation of economy and polity in Polanyi's account of capitalism, he argues that the wedge is "both artificial and historically very rare" (1981:406n).

Still, Polanyi's apparently unambiguous statement that in market society "Instead of [the] economy being embedded in social relations, social relations are embedded in the economic system" (1957:57) appears to support Lie's claim that "[Polanyi's] notion of a market society is of a society in which this disembedded form of interaction becomes its organizing principle"(Lie: 222). Block addresses this ambiguity by suggesting that Polanyi's arguments in The Great Transformation are complex and at times contradictory, with the result that interpretations can easily conflict. He attempts to explain these contradictions by arguing that Polanyi's thought underwent a theoretical shift while writing the book. Given it was also written in a relatively short time, due to limited funding and a desire complete it before the end of the Second World War, Block suggests Polanyi had little opportunity to revise his text following his change of position. In particular, Block suggests that Polanyi's discussion of the commodification of land, labour and money is not entirely consistent. On the one hand, Polanyi's argues clearly that these can be only fictitious commodities, given that they are not produced for sale on the market. On the other hand, it appears as though they can be commodified in so far as they can trade on the 
market in the same way as "true" commodities. However, Polanyi is quite clear that this would lead to the "demolition of society" (1957:79). As I argued above, Polanyi articulated the distinction between embeddedness and separateness not only historically and anthropologically, but also in terms of political economy. From Block's analysis, the seemingly contradictory statements on commodification above can be reconciled in terms of the political articulation of embeddedness: "To avoid the demolition of society, the supply and demand for these fictitious commodities in actual market societies must be managed through the political process" (Block 2003:281). Indeed, in the final chapter of The Great Transformation, Polanyi advocates setting wages outside of the market and putting it in the hands of such institutions as trade unions or the state or other public bodies (1957:259). Block concludes: "Polanyi insists that there can be no pure version of market society because land, labor, and money are not true commodities . . . the system is built on top of a lie that means that it can never work in the way that its proponents claim it works" (2003:281). Block adds that Polanyi should be interpreted as arguing that society cannot be embedded in an autonomous economy, despite the will of market liberals to do so: "Even in market societies ways have to be found to embed labor, land and money in social relations" (2003:282).

Block's interpretation of Polanyi reconciles certain difficulties, and for the remainder of this paper I will interpret Polanyi's work accordingly. ${ }^{4}$ Embeddedness is the reality of social life and disembeddedness is a fiction that can never be truly realized. Put another

\footnotetext{
${ }^{4}$ However, it should be noted that it is not entirely clear that Block's interpretation represents Polanyi's considered position or that apparently contradictory conceptions of the embeddedness/separateness distinction did not persist in Polanyi's later work. In 1977, Polanyi's The Livelihood of Man, was published. It is comprised of unpublished papers and posthumously edited fragments. However, chapter 4, which editor Harry W. Pearson notes was among the chapters, "completed substantially as they appear in this book" (Polanyi, 1977, xxi) begins with the statement: "It was characteristic of the economic system of the nineteenth century that it was institutionally distinct from the rest of society. In a market economy, the production and distribution of material goods is carried on through a self-regulating system of markets, governed by laws of its own, the so-called laws of supply and demand, motivated in the last resort by two simple incentives, fear of hunger and hope of gain" (Polanyi, 1977, 47). It is not clear when this chapter was written.
} 
way, the self-regulating market is an ideological construction that can at best be realized only imperfectly in concrete institutional structures. This does not imply that labor, land or money cannot be partially deregulated so that "with the help of this fiction ... the actual markets for labor, land, and money are organized" (Polanyi 1957:76) or that this kind of deregulation can not have devastating effects. Rather, it means that these will never be fully deregulated. Counter movements will arise long before anything resembling the "stark utopia" or market liberalism is achieved.

\section{Comparisons with Marx, Weber and the Neoclassical Tradition}

At the start of this paper I suggested that those who wish to understanding why free market ideologies are persistent, enjoying a certain popular appeal and continuing to exert a significant influence on public policy today, will not find an answer in Polanyi's work. He offers an historical account of the rise of $19^{\text {th }}$ century capitalism, which is not readily generalizable to contemporary contexts. As Hechter suggests, Polanyi's account is "ad hoc rather than grounded in his own theoretical premises" (1981:423) and concludes: "Polanyi is so enthusiastic about his explanation of the demise of the market that he never even sees the outlines of this equally trenchant problem" (424). This poses a problem for those who, drawing on Polanyi, suggest that the "conflict between the self-regulating market and civil society is a permanent characteristic of capitalist countries" (Baum 1996:12). To further understand the problem I am raising, I will briefly consider how other theoretical perspectives on the origins of capitalism explain its ongoing persistence before offering another alternative in the next section.

In the neoclassical tradition, capitalism is said to have evolved naturally and its institutions are understood in terms of minimizing transaction costs, which improves the ability of economic agents to maximize welfare. Labour markets, private property, money and other economic institutions improve coordination among market participants and improve their ability to make choices in their own best interest. As Hechter notes they arise "more or less spontane- 
ously" and amount to "something like a contract between interested parties" (1981:402). Proponents of this account "argue that the self-regulating market system offered the best available product, that constituents came to realize its comparative advantages and that it gradually won the day" (Hechter 1981:402).

Polanyi clearly rejects this view. His focus on counter movements implies that capitalism did not provide the kinds of advantages which neoclassical theorists suggest. In addition, Polanyi stresses the important role of state intervention and class conflict. ${ }^{5}$ While the Industrial Revolution established the need for a free labour market by the late $18^{\text {th }}$ century, Polanyi argues its institution was prevented by the Speenhamland Law of 1795, which provided rural workers with a minimum income to supplement or replace earnings, as long as they remained in their parish (1957:82). This law was in the interests of the politically dominant rural class (1957:94) and it prevented the establishment of an effective labour market until 1834, when Speenhamland was repealed and the Poor Law Reform Act was passed (101). For Polanyi, the Poor Law Reform was both a victory for the emerging industrial classes and a result of the devastating effects of Speenhamland, which depressed rural wages and productivity and led to the pauperization of rural England (1957:82).

What is important to stress is that the Poor Law Reform, which established an effective labour market, was a political response to a problem caused by earlier political intervention in the form of Speenhamland. As suggested above, changes in the economy and shifting power relations between classes also played an important role in this dynamic. On the surface, this would appear to resonate with a Marxist perspective. Marx linked the emergence of capitalism to the concentration of capital in the hands of the bourgeoisie and the economic decline of feudal landlords. This led to the political and economic ascendancy of the former and the dislocation of the rural peasantry who - through both a need to support themselves and being pressured by accompanying legislation driven by the

\footnotetext{
5 "The road to the free market was opened and kept open by an enormous increase in continuous centrally organized and controlled interventionism" (Polanyi 1957:146).
} 
politically dominant bourgeoisie - provided a ready source of cheap wage-labour. ${ }^{6}$ As a result, an increasingly clear division was created between a small class of bourgeois entrepreneurs who owned the means of production and a large mass of unskilled, non-propertied workers who were hired on a wage basis to produce commodities for sale on the market. Subsequent authors operating in the Marxist tradition have argued that just as capitalism was established through state intervention, further institutional interventions have consolidated the position of the bourgeoisie and allowed capitalism to persist. ${ }^{7}$

Despite Polanyi's emphasis on class and state intervention, his outlook differs substantially from the Marxist position. As Baum notes: "He has little sympathy for the Marxist theory that in a capitalist society the actions of government necessarily aim at protecting the interest of the capitalist class. He rejects the idea that the political order, in this case democracy, is simply a superstructure which reflects power relations defined in economic terms" (1996:10-11). Indeed, Polanyi insists: "Though human society is naturally conditioned by economic factors, the motives of human individuals are only exceptionally determined by the needs of material want-satisfaction" (1957:160). Polanyi stresses that protectionist counter movements cut across the kinds of economic interests that define class for Marxists. Although the latter do not insist that all individuals act in accordance with their economic class interests at a micro-level, it is important to stress that Polanyi is articulating a different dynamic altogether. Specifically, he characterizes capitalist society as a struggle between "the principle of economic liberalism" and "the principle of social protection" (1957:132). As Block and Somers note, although class was important for Polanyi in his historical account of the rise of $19^{\text {th }}$ century capitalism, the Industrial Revolution was viewed as "an exceptional landslide in the history of classes" (2003: 66). More generally, Polanyi writes,

\footnotetext{
${ }^{6}$ A summary of this account is provided in Giddens 1971: 29-35.

${ }^{7}$ For example: Nicos Poulantzas, Classes in Contemporary Capitalism, (London: NLB, 1975); Leo Panitch, "The Role and Nature of the Canadian State" and Rianne Mahon, "Canadian Public Policy: the Unequal Structure of Representation", both in The Canadian State: Political Economy and Political Power (Toronto: University of Toronto Press, 1977).
} 
"Mere class interests cannot offer . . . a satisfactory explanation for any long-run social process" (1957:160).

Recall that, following Block, I interpreted Polanyi as suggesting that the self-regulating market is an ideological construction that can at best be realized only imperfectly in concrete institutional structures. This focus on ideas invites a comparison with Weber. Weber links the emergence of modern capitalism to the protestant work ethic and the way it was practised: "One of the constituents of the modern capitalist spirit, and not only of this, but of modern civilisation generally, the rational conduct of life on the basis of the idea of a calling, thus has its origins, as the present discussion should have shown, in the spirit of Christian asceticism" (1998: 169). However, the persistence of capitalism does not depend on the persistence of that ideology. Capitalism takes on a life of its own. Underlying the ebb and flow of history, for Weber, is a progressive rationalization of society. Capitalism was implemented by two "irrationalities," the notion of a calling and work as an ethic, but the societal dynamic it created is marked by an incredible means-ends efficiency. As Gerth and Mills note, capitalism is seen by Weber as "the highest form of rational operations" (1970:68) and it persists on that basis.

Like Weber, Polanyi stresses the role of ideas in the emergence of capitalism. However, Polanyi directly emphasizes the idea of the self-regulating market which early political economists articulated, rather than tracing its genealogy elsewhere. In addition, he does not offer a reason for which these ideas might persist. Nonetheless, the comparison with Weber suggests we may wish to look for an ideologically grounded theory to explain the persistent influence of the idea of self-regulating markets. In the next section, I will attempt to construct such an account based on G.W.F. Hegel's Phenomenology of Spirit and Jennifer Nedelsky's paper "Reconceiving Autonomy: Sources, Thoughts and Possibilities."

\section{Freedom and the Persistence of Liberal Ideologies}

Hegel understands human consciousness as being driven by a desire for universal recognition. In abstract terms, this means that 
individuals want to be recognized as equals by a community of individuals which they themselves recognize as equals. In Hegel's words, "Each is for the other what the other is for it" (1977:113). This involves each party recognizing the other's inherent right to freely exercise his or her will in relation to the objects of his or her desire. At first glace, this would appear to be a recipe for conflict. Indeed, if two individuals desire the same object, the desire of at least one of them will not be fulfilled, to say nothing of the desire of each for the recognition of the other. But Hegel argues that this is also the basis for genuine community. While an abstract conception of freedom as unconstrained is not possible within such a framework, a more practical freedom is. This involves individuals freely accepting the constraints on action implied by living in a group, while conceiving of and pursuing their specific interests within those constraints. For Hegel, then, the idea of freedom is bound up with the idea of community.

On the surface, this does not appear fundamentally different from the neoclassical view, which could explain the first aspect of Polanyi's double movement but would render the second aspect problematic. But while the influence on Hegel of early British political economists (on whom neoclassical theorists also draw) is clear, his particular conception of human agency is something quite different. As noted, Hegel identifies among human wants not only material or economic goods, but a genuine desire for recognition by equals in which each "exists for another" (1977:111). Freedom involves pursuing one's desires. But since recognition is a fundamental human desire, one can only be free once one obtains that recognition. Hegel thus conceives of the possibility of freedom only as embedded in a particular social structure; rather than defining freedom in terms of a boundary which the state cannot cross, freedom is defined in terms of a society's ability to integrate genuinely autonomous individuals into its broader institutional structure.

Still, as noted above, the desire for recognition can be a source of conflict as well as a force for social integration. Universal recognition is not an automatic state of affairs. While one seeks recognition from another, one must also be free from that other, and this a difficult relationship to negotiate. Throughout human 
history wrong turns on the road to universal recognition abound, leading at times to violent and destructive consequences. Viewed from this perspective, the attempt to construct society according to the ideal of the self-regulated market can be seen as a failed attempt to negotiate freedom and recognition. Counter movements to it can be viewed as an implicit recognition of this failure and an attempt to redress it.

Nedelsky offers a similar perspective, suggesting an explanation of how liberalism may have come to exert such force. Writing as a feminist influenced by the communitarian tradition, she rejects the particular liberal conception of freedom. Taking "atomistic individuals as the basic units of political and legal theory" (Nedelsky 1989:8), liberalism conceives of them as ontologically preceding the state, and thus inhabiting a private sphere which is logically separate from a public sphere of state activity (15). Although society is made up of individuals, their autonomy is defined in opposition to the collective will embodied in the state. The degree of individual autonomy existing within a particular society, therefore, is determined by the degree to which the state is precluded from "interfering" in "private lives." While the boundary between the private and public spheres could conceivably be delimited in a number of ways, as a matter of historical fact, "it was property which was the focal point for this idea" (Nedelsky, 1989:16). The combination of the liberal view of autonomy, combined with a focus on property rights, led to a related distinction between the market, where individuals exercise their rights over property, and politics, which relates to the activities of state and is thus precluded from this private domain. "Free, private, individual (trans)actions stood in defensive opposition to coercive control by collective (public, legislative) power" (Nedelsky 1989:17).

But Nedelsky argues that, in fact, humans do not ontologically precede society; they are not "self-made" in the way liberal theory describes. Rather, "We come into being in a social context that is literally constitutive of us" (8). Viewed in these terms, the opposition between the individual and the state becomes blurred and the dichotomies of "private" or "market" and "public" or "politics" can no longer be taken for granted. This undermines the liberal conception of 
freedom. However, Nedelsky stresses the normative and explanatory importance of maintaining some notion of freedom, suggesting that humans are motivated in part by a desire for autonomy. But understanding individuals as socially embedded requires that autonomy be reconceived on different grounds; it must "encapsulate the emergence of autonomy through relationships with others" (12).

This represents a radical departure from the liberal conception of freedom and Nedesky suggests that reconceiving autonomy along those lines, while possible, will not be easy. The human desire for autonomy involves both a cognitive and a non-cognitive aspect. On a cognitive level, there is a need to believe that one is free. On the non-cognitive level there is a need to feel or experience autonomy. ${ }^{8}$ While she argues that the liberal notion of freedom is illusory and does not provide genuine experience of freedom, it is nonetheless deeply ingrained and cognitively compelling. This is because property provides a particular potent symbol of autonomy: "Two striking and distinguishing characteristics of property are its concreteness and the relative unobtrusiveness of the state power which lies behind it" (Nedelsky, 1989:23). The concreteness of this cognitive link between property and freedom accounts in large part for the "enduring associations between property and autonomy" (23) that make liberalism so compelling.

The cognitive appeal of the liberal conception of freedom is thus able to mask, to a large extent, the fact that liberal autonomy is illusory and does not provide a genuine feeling of autonomy. This explains the persistence of the liberal link between property and autonomy. This does not imply that the non-cognitive aspect of autonomy is without motive force. While concrete but illusory conceptions of freedom can endure for significant periods of time in the absence of genuine feelings of autonomy, the non-cognitive aspect can be seen as exerting pressure on them. ${ }^{9}$ Indeed, the in-

\footnotetext{
${ }^{8}$ Nedelsky, p. 23: "Autonomy is an elusive problem in part because it is practically inseparable from an experience or feeling."

${ }^{9}$ Indeed, it should also be noted that Nedelsky does not see the cognitive and noncognitive aspects as ontologically separate categories, although she distinguishes between them for analytical purposes. The two are linked, and reconceiving autonomy (a cognitive activity) can help one to relearn "what real autonomy feels like" (that is, experience the non-cognitive autonomy). See pp. 24-25.
} 
terplay between the illusory liberal conception of autonomy and a genuine experience of autonomy could be manifested in concrete social conflicts much like the double movement which Polanyi describes. The first aspect of the double movement, which is seen as deliberate and strategic, would correspond with the cognitive aspect of autonomy. The second aspect of the double movement, which Polanyi sees as socially-driven, spontaneous and almost instinctive, would correspond with the non-cognitive aspect of freedom, which Nedelsky sees as involving an autonomy that emerges "through relationships with others" (1989:12). Nedelsky's account is also helpful in that it shows how ideas are developed in negotiation with concrete material conditions. This allows the theorist to make ideological arguments that take class structures, macroeconomic conditions and other historical circumstances into account without reducing ideology to them.

Some further work would be required to fully articulate the link between the Hegel-Nedelsky dynamic of autonomy, as I have developed it, and Polanyi's double movement. For one, the first aspect of the double movement is expressed in macro-level terms. Polanyi talks of the importance of factors such as the technological and social changes of the Industrial Revolution, class conflicts, political struggles and policy interventions. The Hegel-Nedelsky dynamic on the other hand, focuses on the micro-level motivations of individual agents. Nonetheless, I believe that this would not pose an insurmountable problem. Linking the micro to the macro could be done, for example, by arguing that free-market ideas are readily adopted by groups who, given a historically specific set of economic conditions, have a particular interest in deregulation. The groups who are most likely to directly and immediately benefit from deregulation will typically be made up of segments of the business community which have significant financial means at their disposal. They would not only be in a better position to lobby governments, but also to disseminate these free market ideals to a popular audience. Here the rhetoric of freedom as a separation between individuals and the state would find a receptive public. Powerful interests could readily tap into, shape and exploit deeply ingrained but uncritical notions of freedom. This public support 
would legitimize these ideas in the eyes of policy officials who may in any case already be predisposed to them and who may also be under pressure by interested parties to implement them. The dynamic here is neither top-down nor bottom-up. Rather, it involves an interaction between interests, historical circumstances and popular ideologies. This is compatible with Polanyi's suggestion that both class interests and popular, spontaneous and diverse social movements can influence political decisions.

\section{A Polanyian Perspective on Global Financial Deregulation}

To illustrate my argument more clearly, I want to briefly explore how the position I have developed above might fit within a contemporary application of a Polanyian perspective. Specifically, I want to look at two works by Helleiner. Although his States and the Reemergence of Global Finance does not directly make reference the dynamic of the double movement, the influence of Polanyi is evident in his discussions of "embedded liberalism" and the important role played by the state in establishing a deregulated market under the influence not only of concrete interests but of neoliberal ideologies as well. In addition, his paper, "Great Transformations: A Polanyian Perspective on the Contemporary Global Financial Order," refers to many of these same arguments and also considers the existence of counter-movements acting against financial deregulation.

In States and the Reemergence of Global Finance, Helleiner offers an account of the shift from the "embedded liberalism" of Bretton Woods, in which restrictive economic practices including capital controls were endorsed as a means of defending "the policy autonomy of the new interventionist state" (Helleiner 1994:3) to the modern deregulated financial environment based on "neoliberal" ideals, in which capital controls and other regulations are seen as impeding efficiency and personal freedom and in which an unregulated global financial market is seen as an essential mechanism to ensure fiscally disciplined domestic policy (15). Helleiner argues that governments played a decisive role in creating the new global financial regime (8-12). He pays considerable 
attention to changes in the interest structure of various segments of the business community, as well as the technological advancements, economic conditions and institutional changes that made globalization possible. He also argues that an important ideological shift from an "embedded liberalism" to "neoliberalism" took place which focused not only on economic efficiency, but stressed the link between deregulation and freedom. ${ }^{10}$ Helleiner focuses on the adoption of this outlook by key government officials and other policy elites under pressure from interested parties propagating the views of neoliberals such as Friedrich von Hayek and Milton Friedman. However, making an explicit link between policy makers implementing financial deregulation under the influence of class interests and supporting ideologies and broad public support for a neoliberal agenda at the micro-level should not pose a problem. The rhetoric of freedom as a separation between the individual and the state is not only persuasive at elite levels, for they play an important role in electoral politics as well. This may be particularly true in the United States, but these ideologies also exert significant influence in most modern industrial nations.

Given the developments described by Helleiner, one may ask if they have been met with the kinds of counter-movements which Polanyi would predict. Writing in the mid-1990s, Helleiner argues that global financial deregulation has had some "socially dislocating influences" and that there has been some evidence that such movements have begun to emerge (1995:155). However, he argues that the move to a neoliberal global financial order has been relatively unimpeded because of its remoteness from mass consciousness. Not only is its subject matter technical, but deregula-

${ }^{10}$ At several points in States and the Reemergence of Global Finance he emphasizes the neoliberal rhetoric of freedom. For example, Helleiner writes: "Neoliberal advocates favored a liberal international financial order on the grounds that it would enhance personal freedom and promote a more efficient allocation of capital both internationally and domestically" (15). Similarly, "American neoliberals strongly opposed capital controls partly on the grounds that they represented a use of coercive 'police power' by the state that was incompatible with individual liberty and a 'free' form of government" (116). In West Germany and Italy, two countries once governed by fascist regimes, he argues this rhetoric had particular force: "more strict monetary discipline and a move toward free market convertibility were necessary if a return to totalitarianism was to be avoided" (65). 
tion in this sector does not impact any particular social group in a direct and significant way. He uses this to explain why financial deregulation proceeded largely unimpeded, while states took a more protectionist approach to trade policy. He writes, "No specific social group was directly affected in a negative way by the liberalization of capital movements, as is true of the liberalization of trade. Although financial liberalization had important effects on the general public . . . its potentially negative impacts were at the macroeconomic level and were therefore less visible" (1994:204). However, he argues that instabilities and upheavals may raise the awareness and support for measures such as the Tobin tax, which seeks to "discourage speculative cross-border financial movements" that its proponents argue "are causing socially disruptive adjustments to trade patterns and exchange rates as well as reduction in the policy autonomy of governments" (1995:157).

\section{Conclusion: Possibilities and Problems}

In conclusion, I would like to offer two observations. First, the position I have developed based on my interpretation of Hegel and Nedelsky does not imply that a capitalism based on the ideals of a disemebedded self-regulating market is in any way inevitable. Nedelsky says that the liberal conception of freedom on which, to an important extent, modern capitalism relies is particularly compelling but illusory. My interpretation of Hegel implies that the self-regulated market provides an unsatisfactory notion of freedom as opposed to the socially integrated freedom which individuals ultimately, if somewhat unconsciously, seek. They imply, therefore, that a capitalism which continually seeks to disembed markets could persist for some time while also pointing to the possibility, perhaps even the likelihood, of a new form of social organization based on the ideal of embedded markets eventually taking its place. This is compatible with Polanyi's vision of the markets for labour, land and money being socially embedded through the political process, while other markets may remain less regulated. However, the Hegel-Nedelsky dynamic that I have articulated does not necessarily clarify how or when this genuinely embedded society might be realized. 
Nonetheless, it can still explain many of the features of capitalist society which Polanyi highlights and there is no a priori reason to think that further inquiry could not yield further insights.

Second, I suggested above that Polanyi may be vulnerable to a Marxist critique. A full exploration of such a critique can not be made here, but I would like to suggest how it might proceed. To be sure, Polanyi articulates a position that genuinely departs from the Marxist tradition. The former explains the capitalist dynamic in terms of a double movement in which the push for self-regulating markets is met with diverse, spontaneous and relatively disorganized counter movements that cut across class lines and seek to protect social interests. The latter focuses on class struggles based on a clash of economic interests. However, while there are clear differences in theoretical orientation, both seek to explain the same phenomena and it is not clear that historical arguments which Polanyi makes would necessarily prove problematic for the Marxist. First of all, Polanyi emphasizes the importance of ideas. Following Block, I argued that, for Polanyi, capitalism should not be seen as a system in which society is genuinely subordinate to a separate economy. Rather, it is a system which attempts to institutionalize the idea of separateness. While this can not be fully achieved, it can progress to a significant extent. With the addition of the HegelNedelsky dynamic, I argued that the liberal rhetoric of freedom is an important part of facilitating this process. Many Marxists would also claim to be able to account for both the elite and popular acceptance of these ideas. They would likely explain them as superstructural surface phenomena. The Polanyi-Hegel-Nedelsky position I have developed would argue that powerful interests tap into, shape and exploit an unformed, but deeply ingrained, notion of freedom. The Marxist, on the other hand, would claim that such a false consciousness can be instilled without assigning an independent existence to ideas. Without such an independence, the first aspect of the double movement would indeed have much in common with Marxist accounts of the rise and persistence of liberal ideologies.

But what of the second movement? Polanyi bases this more overtly on social interests. He argues that the counter movements challenging the self-regulating market are spontaneous, almost 
instinctual, and involve individuals and groups that cut across class lines. This would appear to directly contradict the Marxist claim that humans are driven by economic class interests. However, historical materialism need not entail a crude or deterministic economism. In the first place, it is not meant to explain human action at the individual, micro-level. Second, certain currents of Marxist thought have been exploring, since at least the 1970s, the role which state, as part of a societal superstructure that reflects a complex class dynamic, plays in fostering both long-term capital accumulation in general and the hegemony of the bourgeoisie. ${ }^{11}$ They argue that this can explain a wide variety of organized group behaviour and seemingly progressive social policy that on the surface may appear to contradict the idea that economic class interests explain mass social behaviour.

Thus, while Polanyi's insistence on the social motivation is at odds with a Marxist emphasis on economic motivation, arbitrating between these theoretical orientations is no simple matter. In practice, there is a fine line between making arguments that show how historical conditions shape ideas and arguments that show how the latter evolve from the former. Devising any kind of "critical test" between the two positions, while not necessarily impossible, would be difficult to do. In the meantime, I have attempted to direct attention to an area of Polanyi's thought that I believe warrants further examination. My hope is that this may prove of value to both those who wish to apply a Polanyian framework and those who wish to criticize it, and ultimately lead to advances in social theory more generally.

\section{References}

Baum, Gregory. 1996. Karl Polanyi on Ethics and Economics. Montreal, QC: McGill-Queen's University Press.

Block, Fred. 2003. "Karl Polanyi and the writing of The Great Transformation." Theory and Society 32:275.

Block, Fred and Margaret R. Somers. 1984. "Beyond the Economistic Fallacy: The Holistic Social Science of Karl Polanyi” Pp. 47-84 in Vision and Method in Historical Sociology, edited by Theda Skocpol. Cambridge, UK: Cambridge University Press.

${ }^{11}$ See note 7 above 
Gerth, H. H. and C. Wright Mills. 1970. "Intellectual Orientations" in From Max Weber: Essays in Sociology, edited and translated by H.H. Gerth and C. Wright Mills. New York, NY: Oxford University Press.

Giddens, Anthony. 1971. Capitalism and modern social theory: An analysis of the writings of Marx, Durkheim and Max Weber. Cambridge, UK: Cambridge University Press.

Hechter, Michael. 1981. "Karl Polanyi’s Social Theory: A Critique." Politics and Society. 10:399.

Hegel, G.W.F. 1977. Phenomenology of Spirit, translated by A.V. Miller. Oxford: Oxford University Press.

Helleiner, Eric. 1994. States and the Reemergence of Global Finance: From Bretton Woods to the 1990s. Ithaca, NY: Cornell University Press.

Helleiner, Eric. 1995. "Great Transformations: A Polanyian Perspective on the Contemporary Global Financial Order". Studies in Political Economy 48 (Autumn): 149.

Lie, John. 1991. "Embedding Polanyi’s Market Society." Sociological Perspectives. 34:219.

Nedelsky, Jennifer. 1989. "Reconceiving Autonomy: Sources, Thoughts and Possibilities." Yale Journal of Law and Feminism. 1(7):7.

Polanyi, Karl. 1957. The Great Transformation. Boston, MA: Beacon Press.

Polanyi, Karl. 1977. The Livelihood of Man, edited by Harry W. Pearson. New York, NY: Academic Press.

Weber, Max. 1998. Max Weber: Selections in Translation, edited by W. Runciman and translated by E. Matthews. Cambridge, UK: Cambridge University Press. 